Article

\title{
Sustainability and Corporate Social Responsibility in the Text of Annual Reports-The Case of the IT Services Industry
}

\author{
Renáta Myšková ${ }^{(1)}$ and Petr Hájek *(i) \\ Faculty of Economics and Administration, University of Pardubice, CZ53210 Pardubice, Czech Republic; \\ renata.myskova@upce.cz \\ * Correspondence: petr.hajek@upce.cz; Tel.: +420-466-03-6067
}

Received: 9 October 2018; Accepted: 6 November 2018; Published: 9 November 2018

check for updates

\begin{abstract}
Annual reports are an important source of qualitative information about a company's strategic areas, including sustainability. However, previous work on sustainability assessment has been limited to quantitative indicators that are difficult to obtain. Here, we address this issue by analyzing a company's strategic documents, with the specific aim of demonstrating the role of sustainability and social responsibility in the text of the annual reports of companies in the IT services industry. We demonstrate that this information is a significant determinant of future economic outcomes. Specifically, here we evaluate sentiment in managerial communication in the area of sustainable business by using collocation analysis of topic and sentiment word lists. Several domain-specific word lists were used for each category monitored. Specifically, Loughran and McDonald's word list was used to measure sentiment in the context of corporate social responsibility and sustainability. The word list that was developed by Pencle and Malaescu was used for CSR, while novel word lists are proposed for sustainability topics. The results of experiments show that the sentiment of sustainability topics (environmental and social in particular) in the annual reports may be a significant indicator of future profitability and thus represent an important information for corporate stakeholders.
\end{abstract}

Keywords: sustainable business practices; sustainable e-business; text analysis; annual report; corporate social responsibility

\section{Introduction}

Currently, increasing attention is being paid to the issues of sustainability and social responsibility. The measure of a company's success is not only its profitability, but rather its overall evaluation relies on quantitative and qualitative characteristics, increasingly reflecting the company's interaction with its surroundings. Therefore, a company's competitiveness is linked not only to economic outcomes, but also to how the company meets its stakeholders' expectations as to the activities it develops for reasons of corporate social responsibility (CSR) and sustainable development [1-3]. Therefore, every company should inform their stakeholders in their annual report about what type of activities they are developing in order to make themselves sustainable and what results they have achieved in this respect.

It can be seen from research in scientific literature that there are a number of academic studies dealing with CSR's influence on companies' economic outcomes [4-6]. However, in our opinion, research focusing on analyzing the text of annual reports from the above perspectives has yet to be conducted. This paper focuses on analyzing textual information that is contained in the annual reports of selected companies with the goal of determining to what extent and in which context do companies 
focusing on electronic business support present their activities concerning sustainability and social responsibility in their annual reports.

IT services companies were selected for this study for the following reasons. IT services use information and communication technology (ICT) as a medium for conducting business activities. They also encompass internal company processes, for example, managing customer relations, managing orders, storage, resource management, product development, etc.- though the emphasis is on the fact that these activities are at least partially executed and managed while using ICT [7]. In the present day, IT services have been increasingly used not only for goods but also for services and, significantly, for information that is provided electronically. As a result, this industry offers an abundance of growth opportunities.

There has been a considerable increase in e-business, particularly in the form of B2C (Business-to-Consumer) that is aimed at final customers. Web applications are increasingly used to realize the relationships between companies and customers. A $17.1 \%$ growth rate was expected for 2017, thanks to the growing number of internet and mobile telephone users in developing markets, the development of more advanced payment and delivery options, important brands opening online shops, and online sellers expanding to new markets [8]. From the above, it can be seen that IT services have become a common element of business dealings. Companies that are active in this field have been registering growing demand, which enables them to achieve better economic outcomes and continue to expand further. However, along with development, it is necessary to ensure sustainability, whose basic tenant can be expressed as maintaining balance between economic success, protecting the environment, and social responsibility. From a strategic perspective, this means focusing on creating customer values, separating growth from resource consumption, and simultaneously reducing one's ecological footprint. The area of IT services appears to be very promising in this respect. Achieving sustainability means being innovative and improving products and services via intelligent solutions, while limiting any negative impact on the quality of human life caused by the business activities. In this respect, sustainability incorporates two aspects:

- achieving higher values-for companies engaging in IT services, it is necessary to support a number of activities within their value chain with software. Some examples of these could be marketing activities including choice of an advertising system, providing communication with customers, ensuring distribution channels, product repair, etc. This is also dependent on the market situation-an increasing number of people are commonly using more devices that connect to the internet (PCs, tablets, mobile telephones); therefore, the need has been growing for software support in specific formats. In conjunction with the key factors for success, the following have been put forward [9]: big data and its use, the website's content and intuitive navigation, augmented reality (i.e., virtual depiction of the product offered), providing multi-channel integration, providing mobile POS (point of sale) terminals, and crowdsourcing; and,

- ensuring a lower impact relating to reduced consumption of resources, limiting storage space, limiting energy consumption, etc. However, it is simultaneously necessary to mention a danger that arises from the electronic means of doing business and commerce, which consists of the abuse of these platforms.

Prior literature has investigated the emphasis that companies place on sustainability using various methods [10], such as the EFQM Excellence Model and sustainability indexes. A global sustainability indicator is represented by the Dow Jones Sustainability Index (DJSI), which has monitored the performance of global companies in terms of economic, environmental, and social criteria since 1999 [11]. However, these approaches to sustainability assessment rely on expert knowledge. Therefore, such an assessment process is considered time consuming and expensive, and so automated systems have become an important issue in sustainability assessment. However, a major problem with these systems is that the sustainability assessment is largely based on qualitative, rather than quantitative, information, with companies' text documents representing an important 
source of the former. Surprisingly, analyzing companies' text documents is a neglected approach in this field. A previous study by Pencle and Malaescu [12] showed that it is possible to effectively measure a company's attitude to CRS this way using IPO prospectuses. For this purpose, a list of words covering CSR topics was designed as part of the paper. In this study, we have gone further and maintain that it is possible to determine companies' attitudes to various sustainability categories (topics) from their annual reports using the same method, as it within such written documents that management discusses key strategic areas of company development. This document thus represents a significant source of information about a company's strategic guidance, even concerning elements of sustainability. The area of CSR, however, does not cover all sustainability issues. Regarding the fact that analogous word lists for the other domains of sustainability are missing from the literature, we have proposed three word lists here for the domains of economic, environmental, and social sustainability. Another inadequacy of previous studies was their concentration on either a topical focus on company texts $[13,14]$ or on overall tone (sentiment) $[15,16]$. The approach that is suggested in this study is unique in that sentiment is investigated inside the context of sustainability. In other words, we investigate management's positive and negative opinions on individual domains of sustainability. This offers a unique perspective on management's opinions and goals regarding these subjects. To show the effectiveness of this approach, we have empirically investigated the options for using it to indicate the future profitability of companies in the IT services industry.

The rest of this paper is organized, as follows. Section 2 reviews related literature and lays out the theoretical background of the research. Based on this background, we pose research hypotheses. Section 3 describes the research methodology, and Section 4 employs regression models to examine the effect of sustainability and CSR sentiment on corporate profitability. Lastly, Section 5 discusses the results and Section 6 concludes the paper.

\section{Literature Review and Hypotheses Development}

\subsection{Communication of Corporate Sustainability, and Corporate Social Responsibility}

Companies that implement CSR in a responsible way are not only able to improve their organizational structure and achieve good results in the area of corporate responsible activities, but they can also achieve sustainable business development [17]. In this context, Benn et al. [18] note that some traditional organizational forms and values need to be significantly reshaped to become sustainable. Dyllick and Hockerts [19] evaluate corporate sustainability in terms of three areas, namely economic, ecological, and social, constituting three types of capital, economic, natural, and social, respectively. Linking the issues of CSR and sustainable company development can even be seen in the demarcation of areas to be evaluated from the perspective of CSR, as well as the areas that are considered significant when evaluating the possibilities for improving company results-economic, social, and environmental. This deals with the integration of economics, society, and the environment (the so-called triple bottom line) for the purpose of achieving success in business [20]. Ciasullo et al. [21] refer to the relevance of social and environmental aspects for consumers' purchasing behavior. One common aspect of both CSR and sustainable development is socially responsible behavior, which focuses on eliminating social problems [22,23] as well as on social initiatives and philanthropic activity [24]. All of this should contribute towards developing the ability to use all business resources intentionally and obtain a competitive advantage [25-27]. Competitive advantage can be developed by engaging in a number of environmentally-oriented activities [28,29], including creating ecological supply chains [30-32]. The result is product-oriented CSR, process-oriented CSR [33], and environmentally-oriented CSR [34].

The reasons for implementing CSR and sustainable development can primarily be seen in overcoming the competition, enhancing company reputation and credibility, and the necessity of complying with the respective legal norms on protecting the environment [35-37]. Implementing CSR and sustainable development principles requires not only an effective organizational structure and effective management, but also motivation and communication with stakeholders. The consumption 
of a specific amount of resources is connected with this, though certain companies are not necessarily able to or do not want to invest these resources [38].

Several studies [39,40] investigated the behavioral models of stakeholders (based on the stakeholder theory developed by Freeman in 1984) and concluded that communication about CSR activities helps to create a positive image about the company's quality and reliability, thus supporting the loyalty and satisfaction of the stakeholders. However, corporate sustainability activities must not be occasional, but rather should be related to core business functions. Otherwise, these activities are perceived negatively [34]. According to several studies [35-37,39], the stakeholder theory is strongly connected with corporate competitiveness.

For United States (U.S.) companies, Swanson [41] identified three factors that encourage companies to commit to CSR: (1) CSR can be utilized to increase sales and profit; (2) stakeholders' behavioral norms are satisfied (also known as negative duty approach); and, (3) weaving the principles of CSR into the company's identity. Focusing on the research of sustainability in the IT services industry, Harmon and Auseklis [42] state that an integrated corporate-wide sustainability strategy is a necessity for IT services to be sustainable. According to their study, only a few organizations consider the full environmental impact of their developed products and services, explained by their short-term focus on reducing costs. CSR is considered to be the primary driver of sustainable IT in several studies [43].

Unfortunately, external pressure on institutionalizing sustainability leads to the result that engaging a greater number of companies decreases the benefits resulting from implementing the related activities [44]. Therefore, the question is whether companies apply and develop CSR intentionally or whether they only present CSR with the purpose of improving their company image [45] or their commercial strategy [46,47]. However, it is generally accepted that CSR activities should also be conducted, owing to their positive effect on corporate financial performance (CFP) [4]. Chandler [48] analyzed more than 20 case studies to illustrate issues related to CSR, including financial, organizational, and societal issues, and also highlighted the importance of strategic CSR. This finding was also supported by the empirical evidence in [49], suggesting that a lack of success in CSR was a major cause of the financial crisis.

The importance of CSR communication was highlighted and a conceptual framework for this communication was developed in [50]. It is argued that such communication is important both in the short-term (supporting stakeholders' favorable behavior and attitudes) as well as in the longer term (affecting stakeholder-company relationships and company's image). In contrast, the lack of the communication is considered to be a barrier to maximize financial benefits from CSR activities. Several communication channels have been proposed for corporate sustainability and CSR in [50], such as annual reports, companies' websites, CSR reports, or advertising. A recent review of literature on CSR communication can be found in [1], identifying legitimacy theory as the dominant theory in examining CSR communication. Companies use their communication channels to manage perceived CSR legitimacy by showing that their activities are appropriate and desirable. Another survey that was performed in [51] finds that minimal releases, such as annual reports and websites, are increasingly preferable communication channels, rather than advertising or company's releases. However, it should also be noted that not all the corporate sustainability and CSR communication is published. Unpublished communication includes that presented in the Intranet, stakeholder dialogue, code of conduct, CSR strategy papers, etc. [2]. Recent empirical findings provide support to the role of CSR communication in achieving U.S. company's business goals [3].

Maignan and Ralston [13] examined qualitative information on CSR presented by the companies on the Internet, and found that 53 percent of U.S. companies mention CSR explicitly on their websites, with a focus on quality of life. Regarding empirical analysis of CSR communication in annual reports, Correa-Garcia et al. [14] investigated CSR communication strategies in 30 non-financial Colombian business groups using content analysis. Their results show that the examined annual reports were employee-oriented. In addition, response and involvement communication strategies were used, rather 
than information communication strategy. To the best of our knowledge, this is the only study using the content analysis of CSR communication. However, it was limited to the identification of stakeholder and communication strategy, thus neglecting the topics and sentiment of the communication.

\subsection{Relationship between Corporate Sustainability, CSR and Financial Performance}

The relationship between using corporate sustainability and CSR and the economic results achieved has been examined in a number of academic studies, often using the evaluation of ratio-based financial indicators as its basis. However, the results of scientific studies are not clear-cut, which has been pointed out by $[52,53]$. To a large extent, this can be explained by the difficulty in evaluating CSR, which is considered to be subjective and affected by many internal and external factors [48]. To address these issues, new CSR indicators have emerged, including the IBM Institute for Business Value's CSR Value Curve [54].

A positive relationship between activities connected to sustainable business and financial performance has been described in the literature for U.S. [55] as well as non-U.S. companies [26,56]. The ROA (Return on Assets) ratio is frequently used to evaluate the influence of CSR [57]. Turban and Greening [58] determined that CSR is positively correlated with ROA for large U.S. companies, while Galbreath [59] similarly states that CSR is positively linked to financial results as measured by ROA and return on equity in research on Australian companies. On the other hand, a negative relationship between CSR and stock market performance was described by Becchetti and Ciciretti [60] for major U.S. stocks, while Brammer et al. [61] noticed a negative relationship between CSR and UK companies' market value. According to Crisóstomo et al. [62], there are positive, negative, and neutral arguments concerning the relationship between CSR and a company's financial performance. Reverte et al. [56] consider CSR in the context of financial and nonfinancial results, and their findings corroborates those of the comparative study by [63]. This study concludes that most previous studies refer to the existence of the relationship between CSR and financial performance. At the same time, there are also studies that suggest CSR has an insignificant [64] or no influence on company performance [6].

In addition to ratio-based financial indicators that derive data from accounting statements, certain studies $[65,66]$ use Tobin's q for judging CSR's influence, on the grounds that it eliminates the distortion of CFP that has originated as a result of using accounting data.

What is fundamental is that the nature of the CSR-CFP relationship is different in conjunction with the field of business, because each field works with a different context and with differing environmental, social, and financial interests [27,67]. Russo and Fouts [68] state that the advantages derived from CSR are greater for sectors with a fast growth rate than for sectors with a slow rate of growth. One of these sectors is information and communication services, supporting the development of e-business, among other things.

As noted above, research to date has tended to focus on evaluating corporate sustainability and CSR while using quantitative indicators. Those overall indicators rely on weights that are assigned to indicators included by using subjective expert knowledge. This may explain the ambiguous findings reported in this subsection. Moreover, a qualitative sustainability assessment should be considered, as reported in [55]. The companies' annual reports are a suitable source for such assessment. In addition, the automatic analysis of the documents do not require expert knowledge, and thus, overcomes the above-mentioned problems. As far as we know, no other authors have analyzed managerial communication in companies' annual reports in the context of sustainability. To fill this gap in the literature, here, we propose a research methodology to analyze managerial communication for the domain of corporate sustainability. We also aim to demonstrate its usefulness for financial performance prediction. Therefore, the following research hypothesis was specified:

Hypothesis 1 (H1). Companies in the IT services industry that communicate more corporate sustainability and CSR activities in their annual reports achieve better financial performance in terms of ROA. 
There are several studies arguing that the positive sentiment of corporate communication in annual reports has a positive impact on the overall CFP of U.S. companies $[15,69]$, as well as their profitability [16,70]. The importance of text in annual reports for CFP prediction was recognized in [71], suggesting that the tone and subjects emphasized are different for poorly performing companies.

Sentiment analysis of annual reports aims to evaluate managerial opinions and emotions toward individuals or topics [72]. Usually, two word categories, negative and positive, are used to evaluate the sentiment (tone) in corporate annual reports. For example, well performing IT companies reportedly used more positive tone of their annual reports, while a less positive tone indicated a worsening of their CFP [73]. Demers and Vega [74] showed that net optimism (i.e., the difference between positive and negative tone) can be used to predict future earnings of U.S. companies. Similarly, Li [16] suggests a clear correlation between the text in annual reports and CFP. Specifically, a more frequent use of positive words is associated with higher future profitability. Dempsey et al. [70] find that poorly performing U.S. companies in terms of ROA have significantly greater annual report opacity. More recently, traditional general dictionaries were replaced with domain-specific financial dictionaries of negative and positive words to show that the prediction accuracy of unexpected earnings can be improved [75]. The findings in [15] suggest that such sentiment information can be effectively used to predict the overall CFP of U.S. companies, expressed in terms of Altman's Z-score. Moreover, the negative sentiment in annual reports and its opacity may create the negative sentiment of stakeholders and decrease their trust, being reflected in the decrease of the company's value [76].

Therefore, based on the above-presented findings, here, it is expected that the sentiment toward corporate sustainability and CSR activities is a significant predictor of corporate profitability. Therefore, it is hypothesized that:

Hypothesis 2 (H1). Companies in the IT services industry that positively present corporate sustainability and CSR activities (with more positive sentiment) in their annual reports achieve better financial performance in terms of $R O A$.

\section{Research Methodology}

The goal of the research is to determine to what extent and in which context (whether or not and how) selected companies present their activities in the area of corporate sustainability and CSR in their annual reports.

In agreement with the above-mentioned studies, we examine the impact of CSR and corporate sustainability on financial performance. However, our assessment is not based on qualitative criteria but on the information that is provided by the management to their stakeholders in annual reports. Adopting the prevailing approach used in previous studies [57], ROA was used to represent CFP. It is worth noting here that a positive relationship has predominantly been proved between ROA, CSR, and corporate sustainability [58,59]. ROA helps investors to evaluate how well company's assets are used to generate profit. Note that profitability can also be measured using ROE and ROS. While ROA measures a company's efficiency at generating profits from assets (including debt and equity), shareholders' equity, and revenue is taken into account in the denominator when calculating ROE and ROS, respectively. In this study, ROA was selected due to its capacity to assess both the efficiency of invested capital and the level of coverage of the company's risky assets.

For text analysis, annual reports of U.S. companies for 2015 were used. Only U.S. companies were included in order to preserve comparability between companies. Specifically, we used the 10-K forms of the U.S. Securities and Exchange Commission as the textual source of annual reports (available at www.sec.gov/edgar.shtml). The annual reports of the non-U.S. companies are provided in different forms (20-F) and thus have different structure and content. Year 2015 was chosen because major U.S. stock exchanges experienced growth in recent years, and, therefore, investor and managerial sentiment has been more positive since 2013, as compared with previous years [77]. The choice of the companies 
that were included in the research was based on the specification of the IT services industry, a field that has been rapidly developed in recent years. E-commerce sales in the year 2016 reached more than 360 million U.S. dollars, and in 2018 it is estimated to be more than 461 million U.S. dollars, with increasing trends expected in the coming years [78]. The selected companies were ones whose main subject of business related to IT support for electronic business or electronic commerce.

Growing demand for these companies' products is the prerequisite for their sales growth, which should be seen in the achievement of excellent economic outcomes. We have assumed that the selected companies behave in a socially responsible way and that they have an excellent company culture. We additionally assume that, because they have access to sensitive information, they have good economic outcomes and thus sufficient finances for CSR activity. In fact, rapid technological changes are the cause of a highly competitive environment in the IT services industry.

We have also assumed that these companies inform their respective interest groups sufficiently, not only about their financial performance, but also about other activities that are associated with sustainable development.

Previous literature has shown that word lists from other domains, such as the General Inquirer (sociology) or DICTION (politics), are not appropriate for sentiment analysis of economic texts, because terms important in the context of financial disclosure are often omitted and negative terms used in these word lists are often positive in an economic context [79]. Therefore, several domain-specific financial word lists, such as those suggested by Loughran and McDonald [75], have been proposed to overcome this issue. Adopting this rationale, we used the word lists by Loughran and McDonald [75] to represent sentiment in the annual reports.

Since we have focused on modeling sentiment in managerial communication for the domain of corporate sustainability, we used specific word lists for each of its categories, i.e., social, economic, and environmental. In the case of CSR, we used a previously developed word list of Pencle and Malaescu [12], which is freely available online (https: / / provalisresearch.com/Download/CSR.zip) and it was utilized effectively to analyze IPO prospectuses in order to predict components of IPO pricing [12]. In other words, this word list was used to measure companies' approach to CSR. Although we adopt this approach here, in contrast to IPO prospectuses, we have evaluated the approach to CSR, as found in the annual reports of the IT services firms. To the best of our knowledge, no such word lists are publicly available for corporate sustainability categories, namely economic, environmental, and social sustainability. Therefore, we created three new word lists to evaluate the frequency of comments that are related to these sustainability topics. Both single words and word phrases were considered in the word lists. Specifically, to develop the word lists, we followed the guidance provided in previous studies $[12,80]$. The word lists are based on several publicly available sustainable development glossaries, such as that of the United Nations (undp.org) and Environmental Protection Agency (epa.ie). Consistent with the previous studies [81] and to ensure the completeness of the word lists, we used the WordNet ontology to detect word synonyms. To ensure deductive content validity [80], three experts in corporate sustainability reviewed the word lists. Furthermore, we assessed their dimensionality on our dataset using correlation matrix, finding no significant correlations between the corporate sustainability dimensions. Their predictive validity was examined in predicting ROA. The word lists are available as the Supplementary Material (Table S1).

To structurally collocate each sustainability topic with its respective sentiment, collocation (co-occurrence) analysis [82] of sustainability (and CSR) and sentiment word lists was performed. Collocations were detected at the sentence level in the WordStat program environment. The Jaccard coefficient was used as a standard measure to calculate the level of co-occurrence [83]. More precisely, this coefficient is defined as the proportion of cases where both word categories occur to the number of cases where at least one of the word categories occurs.

The overall sentiment score for each sustainability topic was calculated as follows:

$$
\text { sentiment }=\frac{\text { collocations }_{\text {positive }}-\text { collocations }_{\text {negative }}}{\text { collocations }}
$$




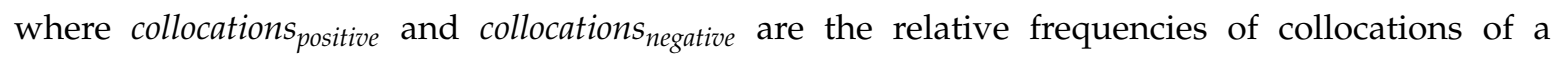
sustainability topic and positive and negative sentiment word categories, respectively. A positive value for this score indicates that positive words predominate in the context of the sustainability topic, while negative sentiment denotes the management's negative opinion on the respective topic. In accordance with numerous related studies [84-86], the relative frequency of the collocations was calculated as raw word category frequency (all words and word phrases were considered to be equally important). To take the negation of positive statements into consideration, the co-occurrences of negation words (e.g., 'no' or 'not') were subtracted from the frequency of positive words [75]. Finally, the word category counts were divided by the number of words in the annual reports to take the length of the annual reports into consideration. In this way, the relative frequencies were obtained.

\section{Experimental Results}

We selected companies from the IT services sector to analyze the influence of the presentation of activities in the area of sustainability and social responsibility in annual reports. As the source of financial data, we used the Value line database and its method of categorizing companies according to sector (sector name: IT services, industry names: E-commerce, Internet and Information services, and Value Line industry codes: 7372, 7370, and 7379, respectively). We obtained financial data and the corresponding annual reports for 2015 as well as for 2016 if there was profitability available in order to predict how it changed. The data were complete for 109 IT services companies out of a total of 325 in this database. A list of their ticker symbols, company names, and industry names is presented in Supplementary Material (Tables S2-S4). The average market capitalization of these firms was USD 2.779 mil.

Table 1 shows the basic descriptive statistics of the variables used. Concerning the frequency with which sustainability topics occurred in the text of the IT services companies' annual reports, CSR issues were mentioned the most, with a rate of occurrence greater than $5 \%$. Less attention was paid to economic and environmental sustainability. It is interesting that the reports' overall sentiment was distinctly negative. In other words, negative words occurred at a greater rate than positive ones. Taking a closer look at the sentiment of the sustainability topics, it is clear that the sentiment is different for these than it is for the subject as a whole. Here, the need to investigate sentiment was confirmed specifically in regards to the individual sustainability topics, and positive sentiment was connected to the area of the environment. For economic sustainability, the average sentiment value was close to zero, i.e., neutral. Last, the average sentiment was negative for CSR, but less than the average for the annual report as a whole. This shows that companies tended to try to supplement sustainability topics with commentary designed to be positive, mostly for problems that are related to the environment.

As hinted above, ROA is considered to be the predominant indicator of financial performance when analyzed in the context of corporate sustainability and CSR. Previous empirical studies generally agree that ROA increases with dividend yield and market-to-book $(\mathrm{P} / \mathrm{B})$ ratio, and decreases with financial market risk [87]. Therefore, these financial indicators were used to control for financial market risk (Beta coefficient). A high $\mathrm{P} / \mathrm{B}$ ratio indicates that investors are expecting high future profit and are willing to pay a premium for that. Note that IT companies tend to have a high $\mathrm{P} / \mathrm{B}$ ratio [88]. Recent empirical evidence also suggests that the sentiment and content of annual reports can be utilized as important indicators of future financial performance [15,77]. Specifically, a positive overall sentiment was shown to be an indicator of higher profitability [77].

The values of the financial ratios indicate that this is a sector with less market risk and a relatively low level of dividend yields. A high level of $\mathrm{P} / \mathrm{B}$ ratio indicates that these companies are positively evaluated by the investors seeking growth opportunities. The average ROA level was positive for both the monitored period of 2015 as well as the future period of 2016. Moreover, there was a further increase in average ROA in the latter period. It is, however, necessary to emphasize that there were high values of standard deviation for all financial ratios. Thus, there are distinct differences in financial performance within this group of companies. 
Table 1. The variables' basic descriptive statistics.

\begin{tabular}{ccc}
\hline Variable & Mean & st.dev. \\
\hline CSR [\%] & 5.02 & 0.61 \\
Corp. sustainability [\%] & 0.59 & 0.15 \\
Corp. sustainability (econ.) [\%] & 0.33 & 0.09 \\
Corp. sustainability (envir.) [\%] & 0.04 & 0.02 \\
Corp. sustainability (social) [\%] & 0.22 & 0.12 \\
Sentiment & -0.382 & 0.126 \\
CSR sentiment & -0.187 & 0.118 \\
Corp. sust. sentiment & 0.157 & 0.335 \\
Corp. sust. (econ.) sent. & 0.000 & 0.338 \\
Corp. sust. (envir.) sent. & 0.166 & 0.706 \\
Corp. sust. (social) sent. & 0.304 & 0.446 \\
Beta & 0.971 & 0.314 \\
Div. Yield [\%] & 0.43 & 1.26 \\
P/B ratio & 8.27 & 25.07 \\
ROA in 2015 [\%] & 6.75 & 9.70 \\
ROA in 2016 [\%] & 9.04 & 13.60 \\
ROA change 2016/2015 & 54.63 & 302.79 \\
\hline
\end{tabular}

Regarding the occurrence of CSR and corporate sustainability topics, CSR was discussed to more extent $(5.02 \%$ on average) in the annual reports as compared with the topics of corporate sustainability $(0.59 \%)$. Among these topics, economic and social sustainability was predominantly communicated. The overall sentiment of the annual reports was negative on average $(-0.382)$. Collocation (co-occurrence) analysis was used to calculate the sentiment of CSR and corporate sustainability topics. When compared to that, CSR and corporate sustainability were communicated in a more positive sentiment, respectively.

There were two sets of experiments that were performed, and generalized linear models were used for both. These models have the absence of multicollinearity between the input variables as a prerequisite, and so we first measured the degree of collinearity using a variance inflation factor. Its values were less than 2.5 in all cases, which indicates that multicollinearity is not present. Another prerequisite when using generalized linear models is the absence of heteroskedasticity. We tested this using the Levene test for the equality of variances. The heteroskedasticity determined was not at the level of significance, $p=0.05$. Similarly, we did not observe first order linear auto-correlation (using the Durbin-Watson test), nor was there significant deviation of the unstandardized residuals from the normal distribution (the Shapiro-Wilk test, everything at a significance level of $p=0.05$ ).

The first experiment was focused on predicting ROA for 2016 using CSR and corporate sustainability, without differentiating individual topics. A generalized linear model was used for this, and its results are presented in Table 2. It is clear from Table 2 that a greater frequency of use of words from the CSR dictionary indicated a lower future ROA. Furthermore, the higher (more positive) the overall sentiment, the higher the future ROA value. However, these effects were not significant. In contrast, the effect of corporate sustainability sentiment was significantly positive. Higher dividend yield also indicated significantly higher ROA. In addition, less risky companies (with lower Beta) achieved significantly higher profitability. The other determinants did not have any significant effect on ROA.

The second model was aimed at determining the influence of input attributes on changes in ROA. To obtain more reliable estimates of the influence, we also used the data collected for 2014. As a result, panel data were used for the second model. A linear mixed model was constructed using the maximum likelihood method for model estimation. Table 3 shows that a positive tone of corporate sustainability serves as an indicator of future growth for ROA. However, CSR sentiment, as well as the frequency of CRS and corporate sustainability words in the texts, were not significant determinants of ROA change. As with the first experiment, Beta affected the ROA change negatively. On the one 
hand, higher dividend yield was, as expected, a positive determinant of ROA change, whereas on the other hand, the negative effect of $\mathrm{P} / \mathrm{B}$ ratio was surprising, suggesting that the growth expectations of investors were not satisfied. This coincides with the negative effect of initial ROA on its future change, which can be explained by the fact that companies with high ROA are financially stable and focus on investing the profits to sustain future profitability. Finally, the fixed effect of year was not significant, suggesting that the results are robust to time period.

Table 2. The Effect of Sustainability, corporate social responsibility (CSR), and Sentiment Indicators on ROA in 2016.

\begin{tabular}{ccccccc}
\hline & $\boldsymbol{b}^{*}$ & st.dev. $\boldsymbol{b}^{*}$ & $\boldsymbol{b}$ & st.dev. $\boldsymbol{b}$ & $\boldsymbol{t}$-Value & $\boldsymbol{p}$-Value \\
\hline Intercept & & & 15.774 & 14.751 & 1.069 & 0.294 \\
CSR & -0.098 & 0.152 & -145.338 & 225.531 & -0.644 & 0.525 \\
CSR sentiment & -0.060 & 0.159 & -4.625 & 12.218 & -0.379 & 0.708 \\
Corp. sustainability & 0.019 & 0.188 & 114.757 & 1126.605 & 0.102 & 0.920 \\
Corp. sust. & 0.405 & 0.186 & 10.999 & 5.048 & 2.179 & $0.038^{* *}$ \\
sentiment & 0.258 & 0.159 & 18.730 & 11.557 & 1.621 & 0.117 \\
Sentiment & -0.306 & 0.156 & -5.193 & 2.649 & -1.960 & $0.060^{*}$ \\
Beta & 0.497 & 0.161 & 10.326 & 3.348 & 3.084 & $0.005^{* * *}$ \\
Div. yield & -0.213 & 0.149 & -0.032 & 0.022 & -1.428 & 0.165 \\
P/B ratio & 0.669 & & & & & \\
$R$ & 0.447 & & & & & \\
$R^{2}$ & 0.403 & & & & & \\
Adj. $R^{2}$ & & & & & & \\
\hline
\end{tabular}

Notes. ${ }^{*}$ statistically significant at a level of $p=0.10,{ }^{* *}$ at a level of $p=0.05,{ }^{* * *}$ at a level of $p=0.01$.

Since CSR and its sentiment were not found to be significant determinants of profitability in the first two experiments, we focused on analyzing the effect of individual topics of corporate sustainability in further experiments. Table 4 shows that the focus on corporate sustainability topics in the annual reports does not indicate better future profitability. However, we were able to find additional evidence for the role of corporate sustainability sentiment in this experiment. More precisely, it is the positive sentiment related to environmental and social sustainability in the annual report that indicates future improvements concerning ROA (Table 4).

Table 3. The effect of Sustainability, CSR, and Sentiment Indicators on the Change in ROA between year $t$ and $t+1, t=\{2014,2015\}$.

\begin{tabular}{ccccc}
\hline & $\boldsymbol{b}$ & st.dev. $\boldsymbol{b}$ & $\boldsymbol{t}$-Value & $\boldsymbol{p}$-Value \\
\hline Intercept & 0.419 & 6.132 & 0.071 & 0.917 \\
CSR & -6.000 & 92.343 & -0.069 & 0.900 \\
CSR sentiment & -5.481 & 4.957 & -1.103 & 0.285 \\
Corp. sustainability & 172.137 & 457.200 & 0.377 & 0.710 \\
Corp. sust. sentiment & 5.786 & 2.093 & 2.774 & $0.025^{* *}$ \\
Sentiment & 1.502 & 4.933 & 0.300 & 0.771 \\
Beta & -2.580 & 1.098 & -2.355 & $0.029^{* *}$ \\
Div. yield & 2.916 & 1.496 & 1.955 & $0.068^{*}$ \\
P/B ratio & -0.030 & 0.011 & -3.362 & $0.042^{* *}$ \\
ROA in year $t$ & -0.221 & 0.065 & -3.386 & $0.017^{* *}$ \\
Year $=t$ & 0.419 & 6.132 & 0.071 & 0.917 \\
\hline$R$ & 0.728 & & & \\
$R^{2}$ & 0.530 & & & \\
Adj. $R^{2}$ & 0.482 & & & \\
\hline
\end{tabular}

Notes. ${ }^{*}$ statistically significant at a level of $p=0.10,{ }^{* *}$ at a level of $p=0.05$.

Finally, the results in Table 5 show that the sentiment of environmental sustainability can also be used as the indicator of change in ROA. Again, this effect was significantly positive, suggesting 
that communicating the environmental sustainability in positive tone indicates future growth in ROA. The effects of the remaining variables are in agreement with those that are reported in Table 3.

Table 4. The Effect of Sustainability Topics and Sentiment Indicators on ROA in 2016.

\begin{tabular}{|c|c|c|c|c|c|c|}
\hline & $b^{*}$ & st.dev. $b$ * & $b$ & st.dev. $b$ & $t$-Value & $p$-Value \\
\hline Intercept & & & -2.125 & 7.739 & -0.275 & 0.786 \\
\hline Corp. sust. (econ.) & -0.028 & 0.191 & -218.266 & 1476.904 & -0.148 & 0.884 \\
\hline Corp. sust. (envir.) & 0.064 & 0.172 & 632.808 & 1692.167 & 0.374 & 0.711 \\
\hline Corp. sust. (social) & 0.075 & 0.161 & 3245.281 & 6946.708 & 0.467 & 0.644 \\
\hline $\begin{array}{l}\text { Corp. sust. } \\
\text { (econ.)-sent. }\end{array}$ & -0.166 & 0.189 & -4.474 & 5.093 & -0.878 & 0.388 \\
\hline $\begin{array}{l}\text { Corp. sust. } \\
\text { (envir.)-sent. }\end{array}$ & 0.369 & 0.173 & 4.754 & 2.235 & 2.127 & $0.043^{* *}$ \\
\hline $\begin{array}{l}\text { Corp. sust. } \\
\text { (social)-sent. }\end{array}$ & 0.295 & 0.171 & 6.020 & 3.500 & 1.720 & 0.097 * \\
\hline Beta & -0.191 & 0.168 & -3.235 & 2.840 & -1.139 & 0.265 \\
\hline Div. yield & 0.439 & 0.171 & 9.103 & 3.542 & 2.570 & $0.016^{* * *}$ \\
\hline $\mathrm{P} / \mathrm{B}$ ratio & -0.232 & 0.147 & -0.034 & 0.022 & -1.577 & 0.127 \\
\hline$R$ & 0.674 & & & & & \\
\hline$R^{2}$ & 0.454 & & & & & \\
\hline Adj. $R^{2}$ & 0.398 & & & & & \\
\hline
\end{tabular}

Table 5. The Effect of Sustainability Topics and Sentiment Indicators on the Change in ROA between year $t$ and $t+1, t=\{2014,2015\}$.

\begin{tabular}{|c|c|c|c|c|}
\hline & $b$ & st.dev. $b$ & $t$-Value & $p$-Value \\
\hline Intercept & 0.180 & 3.228 & 0.059 & 0.911 \\
\hline Corp. sust. (econ.) & 275.238 & 615.774 & 0.441 & 0.673 \\
\hline Corp. sust. (environ.) & 311.815 & 704.099 & 0.446 & 0.647 \\
\hline Corp. sust. (social) & -994.480 & 2914.923 & -0.347 & 0.672 \\
\hline Corp. sust. (econ.)-sent. & 2.206 & 2.202 & 1.006 & 0.329 \\
\hline Corp. sust. (envir.)-sent. & 2.145 & 0.957 & 2.244 & $0.038^{* * *}$ \\
\hline Corp. sust. (social)-sent. & 1.385 & 1.511 & 0.921 & 0.372 \\
\hline Beta & -2.293 & 1.184 & -1.941 & $0.070 *$ \\
\hline Div. yield & 2.703 & 1.577 & 1.719 & 0.109 \\
\hline $\mathrm{P} / \mathrm{B}$ ratio & -0.029 & 0.011 & -3.154 & $0.049 * *$ \\
\hline ROA in year $t$ & -0.201 & 0.070 & -2.851 & $0.034^{* *}$ \\
\hline Year $=t$ & 0.341 & 1.079 & -0.704 & 0.484 \\
\hline$R$ & 0.715 & & & \\
\hline$R^{2}$ & 0.511 & & & \\
\hline Adj. $R^{2}$ & 0.455 & & & \\
\hline
\end{tabular}

\section{Discussion}

The companies studied do present activity relating to sustainable development in their annual reports. It can be seen from the results above that information on activities in the field of CSR are primarily included in the annual reports; however, CSR was presented with a negative overtone, which does not correspond with the assumption that including a presentation of sustainable development and especially CSR activities in annual reports would target a positive perception of the company by stakeholders. The reason for this could be concerns on the part of the management related to the possible growth of expenses linked to sustainability and CSR activities, which would lead to weakening the company's economic outcomes and subsequently potential problems, such as explaining to the stockholders that there was a decrease in previously high dividend yield levels. 
For the area of the environment, there is a clear attempt to comment positively on environmental activity and target all stakeholders with this information. This corresponds with theoretical findings from the field of psychological analysis, where participating parties react positively to social responsibility concerning the environment. From the perspective of the companies' management, when taking into consideration impending changes in today's rather complicated business environment, a proactive environmental strategy can achieve a competitive advantage [89], because it is difficult for the competition to emulate the specific information and environmental experience that has been obtained. The average value of sentiment for economic sustainability was near zero (i.e., neutral), which corresponds to a realistic evaluation of economic outcomes.

Distinct differences were determined for the group of companies concerning their financial performance. In summary, Hypothesis 1 was not confirmed, meaning that there was no evidence to suggest that there is a positive effect of more frequent communication of corporate sustainability and CSR activities in annual reports on profitability. Therefore, the answer to the question of whether companies that achieve greater profitability (measured using ROA) present activities relating to sustainable development more often was disapproved. This finding is also in agreement with a non-significant effect of CSR communication through annual reports on U.S. companies' business goals that were observed by Lim and Greenwood [3]. It is clear from the annual reports that the companies are primarily focused on explaining economic outcomes and on economic sustainability, even if, as has been mentioned, the sentiment in this area was found to be neutral.

In light of the legitimacy theory, we confirmed that U.S. companies voluntarily report on their CSR activities in annual reports, as expected by their stakeholders [1]. More precisely, we provide an empirical evidence for the importance of presenting corporate sustainability in positive tone for perceived corporate sustainability legitimacy. Thus, our findings support the role of CSR and corporate sustainability communication in achieving U.S. company's business goals, as observed earlier in [45]. We also provide additional evidence in support of role of CSR and corporate sustainability topics in public communication channels, but unlike earlier studies $[13,14]$, we argue for the importance of sentiment used in the context of those topics.

Hypothesis 2 was focused on the effect of sentiment in the context of CSR and corporate sustainability on future profitability. Hypothesis 2 was confirmed for both future ROA and its growth. This was true for environmental and social sustainability, in particular. Confirmation of Hypothesis 2 supports the findings of Swanson [41], arguing that CSR is motivated not only by its contribution to improving business results, especially profitability, but also by the need to meet stakeholders' expectations and promote corporate identity. A positive presentation of CSR activities certainly promotes both the satisfaction of stakeholders and corporate identity. This corroborates the prospect theory of Kahneman and Tversky [90], emphasizing that a company's stakeholders process information asymmetrically, and thus, emotional information may outweigh the extent to which CSR and corporate sustainability is communicated. Confirming the need for a positive CSR presentation for a positive corporate perception also complements the lessons learnt from the global financial crisis (2007-2010) [49]. Specifically, the financial crisis is mainly attributed to the separation thesis, making business and ethics mutually exclusive. Sun and Bellamy [49] argue that the fast-growing CSR initiatives and the enlightened stakeholder model both promote building a connection thesis, contradicting the traditional separation of business and ethics. Therefore, our results provide additional empirical support for the connection thesis, interrelating the way that managers communicate corporate sustainability and future CFP.

Regarding the role of sentiment in corporate annual reports, our study contributes to the earlier literature by adding specific sustainability context. In contradiction with earlier findings for U.S. companies [16,70], we did not observe the positive effect of the overall sentiment in annual reports on profitability. However, we argue that the context of the sentiment is important for profitability prediction, and that, in agreement with [15], domain-specific dictionaries can be effectively used to predict profitability of U.S. companies. These findings can be explained by the increasing importance of 
managerial communication with stakeholders, especially after the financial crisis. Moreover, managers have realized that the tone of their communication may affect the stakeholders' expectations, and therefore, may attempt to intentionally adjust the overall sentiment in different contexts. Taken together, our findings suggest a role for sustainability context in developing automated systems for sentiment analysis of managerial communication.

Taking into account the considerations so far, which emphasize the importance of environmental and social activities in particular, the results of this study can serve as an effective decision-support tool for managers and stakeholders. Managers communicate these activities in annual reports, while stakeholders use this communication to make financial decisions. The textual analysis of companies' annual reports performed in the context of ROA can also be used in strategic management. In agreement with managerial theories [3,14], CSR is important to understand as part of a company's strategy because CSR promotes relationships with stakeholders. CSR activities are associated with different social and environmental needs, and are therefore considered to be critical in the long run. It is necessary not only to take them into account in defining business objectives but also to present them appropriately inside and outside the company.

This study proposed a novel approach to evaluate sentiment in annual reports in the context of CSR and corporate sustainability. This process is automatic and does not require expert knowledge in evaluating CSR and corporate sustainability activities. However, it should be noted that the main disadvantage of this proposed approach is that it relies on the information that is provided by the company's management in their annual reports. Other strategic documents, such as websites and corporate CSR reports [53], could also be utilized in future studies to enhance the relevance of this approach. Similarly, reports from external experts on CSR and corporate sustainability may be available for some companies. These can also provide valuable information on these activities. For comparative purposes, we also recommend the application of this approach in other industries, such as other high-tech services and high-tech manufacturing. Another limitation of this study is the use of a dictionary-based approach. Although we addressed the problem of context-specific nature of sustainable development vocabulary, machine learning approaches, such as deep neural networks, may provide more accurate evaluations of sentiment [91]. However, it must be noted that those approaches are difficult to interpret.

In addition to the above-mention contribution, the results of this study have several important implications for companies' managers and stakeholders. Managers of well-performing IT services companies do not properly communicate the CSR in their annual reports, and neither frequency nor sentiment indicate future development in profitability. When interpreting the managerial comments on corporate sustainability, stakeholders of these companies should perceive the sentiment used in this context, rather than the extent to which these activities are discussed. Although this study has gone some way towards enhancing our understanding of the information presented in annual reports in the context of sustainability, more research is needed to generalize our findings. Therefore, we believe that subsequent studies will validate our findings by examining a greater quantity of companies.

\section{Conclusions}

This study set out to determine the effect of CSR and corporate sustainability in the text of the annual reports of IT services companies on their profitability. To do so, we proposed a novel approach to analyze the content of annual reports that are related to CSR and corporate sustainability. This approach integrates the word lists that were developed for these topics with those used for sentiment analysis. When we focused on individual areas of sustainability, their corresponding sentiment substantially differed, and so sentiment was evaluated by taking the individual sustainability topics into consideration. This was found to be important also when analyzing the effect of these topics on corporate profitability.

Future ROA growth is connected to positive sentiment of corporate sustainability, lower market risk, and higher dividend yields, but not with a higher occurrence of information about CSR and 
sustainable development. Regarding the components of sentiment, information that is related to environmental and social sustainability appears to be positive. It can be said that annual reports written using positive language and that emphasize environmental and social sustainability indicate future improvement for the ROA ratio. This relates to the fact that company managements increasingly monitor environmental and social sustainability in a targeted way, evaluate potential environmental risk, and prioritize employee satisfaction. Conversely, when a greater number of words from the CSR or corporate sustainability dictionary are used, this does not point to a significant change in ROA in the future. The reason could be alternative business goals that are linked to the development of CSR and corporate sustainability activities to the detriment of profitability.

In conclusion, it can be stated that companies focus on presenting their activities in the area of the environment positively, which is given not only on account of the toughening legislative conditions and the necessity of meeting defined responsibilities for protecting the environment, but also with the change in all stakeholders' approach toward environmental policy. Even though there is a trend to create separate environmental reports, annual reports are still an important source of information. In the economic domain, management needs to explain the results that were attained and outline a method for achieving economic sustainability in the future. Management's goal is to achieve competitive advantage and to ensure the stakeholders take a positive approach. Therefore, the sentiment of corporate sustainability and CSR contained in annual reports does have significance, and society and academic enquiry should pay more attention to it than they have up to now.

Supplementary Materials: The following are available online at http:/ / www.mdpi.com/2071-1050/10/11/4119/ s1. Table S1: List of companies; Table S2: Word list for economic corporate sustainability; Table S3: Word list for environmental corporate sustainability; Table S4: Word list for social corporate sustainability.

Author Contributions: Both authors participated equally in the definition of research hypotheses and model design. R.M. developed the word lists used in research calculations; P.H. conducted the experiments. Conclusions are processed by both authors together.

Funding: This work was supported by a grant provided by the scientific research project of the Czech Sciences Foundation Grant No. 16-19590S.

Acknowledgments: We gratefully acknowledge the help provided by constructive comments of the anonymous referees.

Conflicts of Interest: The authors declare no conflict of interest. The founding sponsors had no role in the design of the study; in the collection, analyses, or interpretation of data; in the writing of the manuscript, and in the decision to publish the results.

\section{References}

1. Crane, A.; Glozer, S. Researching corporate social responsibility communication: Themes, opportunities and challenges. J. Manag. Stud. 2016, 53, 1223-1252. [CrossRef]

2. Seele, P.; Gatti, L. Greenwashing revisited: In search of a typology and accusation-based definition incorporating legitimacy strategies. Bus. Strategy Environ. 2015, 26, 239-252. [CrossRef]

3. Lim, J.S.; Greenwood, C.A. Communicating corporate social responsibility (CSR): Stakeholder responsiveness and engagement strategy to achieve CSR goals. Public Relat. Rev. 2017, 43, 768-776. [CrossRef]

4. Saeidi, S.P.; Sofian, S.; Saeidi, P.; Saeidi, S.P.; Saaeidi, S.A. How does corporate social responsibility contribute to firm financial performance? The mediating role of competitive advantage, reputation, and customer satisfaction. J. Bus. Res. 2015, 68, 341-350. [CrossRef]

5. DiSegni, D.M.; Huly, M.; Akron, S. Corporate social responsibility, environmental leadership and financial performance. Soc. Responsib. J. 2015, 11, 131-148. [CrossRef]

6. McWilliams, A.; Siegel, D. Corporate social responsibility and financial performance: Correlation or misspecification? Strateg. Manag. Res. 2001, 21, 603-609. [CrossRef]

7. Suchánek, P. E-Commerce: Electronic Business and Conception of Electronic Commerce, 1st ed.; Ekopress: Prague, Czech Republic, 2012. (In Czech)

8. eMarketer. Worldwide B2C Ecommerce: 2013 Forecast and Comparative Estimates. Available online: https:/ / www.emarketer.com/Coverage/ConsumersEcommerce.aspx (accessed on 2 April 2018). 
9. E-commerce Magazin. E-Commerce-Trends. 2014. Available online: http://www.e-commerce-magazin.de/ ecm/news/e-commerce-trends-2014 (accessed on 4 April 2018).

10. Jankalova, M.; Jankal, R. The assessment of corporate social responsibility: Approaches analysis. Entrep. Sustain. 2017, 4, 441-459. [CrossRef]

11. López, M.V.; Garcia, A.; Rodriguez, L. Sustainable development and corporate performance: A study based on the Dow Jones sustainability index. J. Bus. Ethics 2007, 75, 285-300. [CrossRef]

12. Pencle, N.; Mălăescu, I. What's in the words? Development and validation of a multidimensional dictionary for CSR and application using prospectuses. J. Emerg. Technol. Account. 2016, 13, 109-127. [CrossRef]

13. Maignan, I.; Ralston, D.A. Corporate social responsibility in Europe and the U.S.: Insights from businesses' self-presentations. J. Int. Bus. Stud. 2002, 33, 497-514. [CrossRef]

14. Correa-Garcia, J.A.; Garcia-Benau, M.A.; Garcia-Meca, E. CSR Communication strategies of Colombian business groups: An analysis of corporate reports. Sustainability 2018, 10, 1602. [CrossRef]

15. Hájek, P.; Olej, V.; Myšková, R. Forecasting corporate financial performance using sentiment in annual reports for stakeholders' decision-making. Technol. Econ. Dev. Econ. 2014, 20, 721-738. [CrossRef]

16. Li, F. Annual report readability, current earnings, and earnings persistence. J. Account. Econ. 2008, 45, 221-247. [CrossRef]

17. Wang, Z.; Sarkis, J. Investigating the relationship of sustainable supply chain management with corporate financial performance. Int. J. Prod. Perform. Manag. 2013, 62, 871-888. [CrossRef]

18. Benn, S.; Edwards, M.; Williams, T. Organizational Change for Corporate Sustainability, 3rd ed.; Routledge: London, UK, 2014.

19. Dyllick, T.; Hockerts, K. Beyond the business case for corporate sustainability. Bus. Strategy Environ. 2002, 11, 130-3141. [CrossRef]

20. Van Marrewijk, M. Concepts and definitions of CSR and corporate sustainability: Between agency and communion. J. Bus. Ethics 2003, 44, 95-105. [CrossRef]

21. Ciasullo, M.V.; Maione, G.; Torre, C.; Troisi, O. What about sustainability? An empirical analysis of consumers' purchasing behavior in fashion context. Sustainability 2017, 9, 1617. [CrossRef]

22. Huffman, M.L. Organizations, managers, and wage inequality. Sex Roles 2013, 68, 216-222. [CrossRef]

23. Jankalova, M. Approaches to the evaluation of corporate social responsibility. Procedia Econ. Financ. 2016, 39, 580-587. [CrossRef]

24. Labuschagne, C.; Brent, A.C. An industry perspective of the completeness and relevance of a social assessment framework for project and technology management in the manufacturing sector. J. Clean. Prod. 2008, 16, 253-262. [CrossRef]

25. Torugsa, N.A.; O'Donohue, W. Capabilities, proactive CSR and financial performance in SMEs: Empirical evidence from an Australian manufacturing industry sector. J. Bus. Ethics 2012, 109, 483-500. [CrossRef]

26. Nakamura, E. The bidirectional CSR investment-Economic performance relationship. J. Glob. Responsib. 2015, 6, 128-144. [CrossRef]

27. Schreck, P. Reviewing the business case for corporate social responsibility: New evidence and analysis. J. Bus. Ethics 2011, 103, 167-188. [CrossRef]

28. Reinhardt, F.L. Bringing the environment down to earth. Harv. Bus. Rev. 1999, 77, 149-157. [PubMed]

29. Sarkis, J. Convincing industry that there is value in environmentally supply chains. Probl. Sustain. Dev. 2009, 4, 61-64.

30. Henri, J.F.; Journeault, M. Eco-control: The influence of management control systems on environmental and economic performance. Account. Organ. Soc. 2010, 35, 63-80. [CrossRef]

31. Wolf, J. The relationship between sustainable supply chain management, stakeholder pressure and corporate sustainability performance. J. Bus. Ethics 2014, 119, 317-328. [CrossRef]

32. Agan, Y.; Kuzey, C.; Acar, M.F.; Açıkgoz, A. The relationships between corporate social responsibility, environmental supplier development, and firm performance. J. Clean. Prod. 2016, 112, 1872-1881. [CrossRef]

33. Kurapatskie, B.; Darnall, N. Which corporate sustainability activities are associated with greater financial payoffs? Bus. Strategy Environ. 2013, 22, 49-61. [CrossRef]

34. Jayachandran, S.; Kalaignanam, K.; Eilert, M. Product and environmental social performance: Varying effect on firm performance. Strateg. Manag. J. 2013, 34, 1255-1264. [CrossRef]

35. Archel, P.; Husillos, J.; Spence, C. The institutionalisation of unaccountability: Loading the dice of corporate social responsibility discourse. Account. Organ. Soc. 2011, 36, 327-343. [CrossRef] 
36. Contrafatto, M. The institutionalization of social and environmental reporting: An Italian narrative. Account. Organ. Soc. 2014, 39, 414-432. [CrossRef]

37. Tang, Z.; Hull, C.E.; Rothenberg, S. How corporate social responsibility engagement strategy moderates the CSR-financial performance relationship. J. Manag. Stud. 2012, 49, 1274-1303. [CrossRef]

38. Engert, S.; Baumgartner, R.J. Corporate sustainability strategy bridging the gap between formulation and implementation. J. Clean. Prod. 2015, 113, 822-834. [CrossRef]

39. Schuler, D.A.; Cording, M. A corporate social performance- corporate financial performance behavioral model for consumers. Acad. Manag. Rev. 2006, 31, 540-558. [CrossRef]

40. Wang, T.; Bansal, P. Social responsibility in new ventures: Profiting from a long-term orientation. Strateg. Manag. J. 2012, 33, 1135-1153. [CrossRef]

41. Swanson, D.L. Addressing a theoretical problem by reorienting the corporate social performance model. Acad. Manag. Rev. 1995, 20, 43-64. [CrossRef]

42. Harmon, R.; Auseklis, N. Sustainable IT services: Assessing the impact of green computing practices. In Proceedings of the 2009 Portland International Conference on Management of Engineering \& Technology, Portland, OR, USA, 2-6 August 2009; pp. 1707-1717.

43. Zarella, E. Sustainable IT: The Case for Strategic Leadership; KPMG IT Advisory: Amstelveen, The Netherlands, 2008.

44. Flammer, C. Does product market competition foster corporate social responsibility? Evidence from trade liberalization. Strateg. Manag. J. 2015, 36, 1469-1485. [CrossRef]

45. Kim, Y.; Park, M.S.; Wier, B. Is earnings quality associated with corporate social responsibility? Account. Rev. 2012, 87, 761-796. [CrossRef]

46. Scherer, A.G.; Palazzo, G. The new political role of business in globalized world: A review of a new perspective on CSR and its implications for the firm, governance, and democracy. J. Manag. Stud. 2011, 48, 899-931. [CrossRef]

47. Windolph, S.E.; Harms, D.; Schaltegger, S. Motivations for corporate sustainability management: Contrasting survey results and implementation. Corp. Soc. Responsib. Environ. Manag. 2014, 21, 272-285. [CrossRef]

48. Chandler, D. Strategic Corporate Social Responsibility Sustainable Value Creation, 4th ed.; SAGE Publication: Thousand Oaks, CA, USA, 2007.

49. Sun, W.; Bellamy, L. Who is responsible for the financial crisis? Lessons from a separation thesis. In Reframing Corporate Social Responsibility: Lessons from the Global Financial Crisis; Emerald Group Publishing Limited: Bingley, UK, 2010; Volume 1, pp. 101-124.

50. Du, S.; Bhattacharya, C.B.; Sen, S. Maximizing business returns to corporate social responsibility (CSR): The role of CSR communication. Int. J. Manag. Rev. 2010, 12, 8-19. [CrossRef]

51. Morsing, M.; Schultz, M. Corporate social responsibility communication: Stakeholder information, response and involvement strategies. Bus. Ethics Eur. Rev. 2006, 15, 323-338. [CrossRef]

52. Javed, M.; Rashid, M.A.; Hussain, G. When does it pay to be good-A contingency perspective on corporate social and financial performance: Would it work? J. Clean. Prod. 2016, 133, 1062-1073. [CrossRef]

53. Seele, P.; Lock, I. Instrumental and/or deliberative? A typology of CSR communication tools. J. Bus. Ethics 2015, 131, 401-414. [CrossRef]

54. Pohle, G.; Hittner, J. Attaining Sustainable Growth through Corporate Social Responsibility; IBM Institute for Business Value: Somers, NY, USA, 2008.

55. Weber, M. The business case for corporate social responsibility: A company-level measurement approach for CSR. Eur. Manag. J. 2008, 26, 247-261. [CrossRef]

56. Reverte, C.; Gomez-Melero, E.; Cegarra-Navarro, J.G. The influence of corporate social responsibility practices on organizational performance: Evidence from eco-responsible Spanish firms. J. Clean. Prod. 2016, 112, 2870-2884. [CrossRef]

57. Kimmel, P.D.; Weygandt, J.J.; Kieso, D.E. Financial Accounting: Tools for Business Decision Making, 7th ed.; John Wiley \& Sons: Hoboken, NJ, USA, 2013.

58. Turban, D.B.; Greening, D.W. Corporate social performance and organizational attractiveness to prospective employees. Acad. Manag. J. 1996, 40, 658-672.

59. Galbreath, J. Does primary stakeholder management positively affect the bottom line? Some evidence from Australia. Manag. Decis. 2006, 44, 1106-1121. [CrossRef]

60. Becchetti, L.; Ciciretti, R. Corporate social responsibility and stock market performance. Appl. Financ. Econ. 2009, 19, 1283-1293. [CrossRef] 
61. Brammer, S.; Brooks, C.; Pavelin, S. Corporate social performance and stock returns: UK evidence from disaggregate measures. Financ. Manag. 2006, 35, 97-116. [CrossRef]

62. Crisóstomo, V.L.; Freire, F.S.; Vasconcellos, F.C. Corporate social responsibility, firm value and financial performance in Brazil. Soc. Responsib. J. 2011, 7, 295-309. [CrossRef]

63. Salzmann, O.; Ionescu-Somers, A.; Steger, U. The business case for corporate sustainability: Literature review and research options. Eur. Manag. J. 2005, 23, 27-36. [CrossRef]

64. Surroca, J.; Tribo, J.A.; Waddock, S. Corporate responsibility and financial performance: The role of intangible resources. Strateg. Manag. J. 2010, 31, 463-490. [CrossRef]

65. Peloza, J. The challenge of measuring financial impacts from investments in corporate social performance. J. Manag. 2009, 35, 1518-1541. [CrossRef]

66. Servaes, H.; Tamayo, A. The impact of corporate social responsibility on firm value: The role of customer awareness. Manag. Sci. 2013, 59, 1045-1061. [CrossRef]

67. Baird, P.; Geylani, P.; Roberts, J. Corporate social and financial performance re-examined: Industry effects in a linear mixed model analysis. J. Bus. Ethics 2012, 109, 367-388. [CrossRef]

68. Russo, M.V.; Fouts, P.A. A resource-based perspective on corporate environmental performance and profitability. Acad. Manag. J. 1997, 40, 534-559.

69. Cecchini, M.; Aytug, H.; Koehler, G.J.; Pathak, P. Making words work: Using financial text as a predictor of financial events. Decis. Support Syst. 2010, 50, 164-175. [CrossRef]

70. Dempsey, S.J.; Harrison, D.M.; Luchtenberg, K.F.; Seiler, M.J. Financial opacity and firm performance: The readability of REIT annual reports. J. Real Estate Financ. Econ. 2012, 45, 450-470. [CrossRef]

71. Kohut, G.F.; Segars, A.H. The president's letter to stockholders: An examination of corporate communication strategy. J. Bus. Commun. 1992, 29, 7-21. [CrossRef]

72. Medhat, W.; Hassan, A.; Korashy, H. Sentiment analysis algorithms and applications: A survey. Ain Shams Eng. J. 2014, 5, 1093-1113. [CrossRef]

73. Magnusson, C.; Arppe, A.; Eklund, T.; Back, B.; Vanharanta, H.; Visa, A. The language of quarterly reports as an indicator of change in the company's financial status. Inf. Manag. 2005, 42, 561-574. [CrossRef]

74. Demers, E.A.; Vega, C. Soft Information in Earnings Announcements: News or Noise? Working Paper; INSEAD, 2010. Available online: http://www.federalreserve.gov/pubs/ifdp/2008/951/ifdp951.pdf (accessed on 14 August 2018).

75. Loughran, T.; McDonald, B. When is a liability not a liability? Textual analysis, dictionaries, and 10-Ks. J. Financ. 2011, 66, 35-65. [CrossRef]

76. Baxamusa, M.; Jalal, A.; Jha, A. It pays to partner with a firm that writes annual reports well. J. Bank. Financ. 2018, 92, 13-34. [CrossRef]

77. Myšková, R.; Hájek, P. Comprehensive assessment of firm financial performance using financial ratios and linguistic analysis of annual reports. J. Int. Stud. 2017, 10, 96-108. [CrossRef] [PubMed]

78. Statista. The Statistic Portal. Available online: https://www.statista.com/statistics/272391/us-retail-ecommerce-sales-forecast (accessed on 14 August 2018).

79. Henry, E.; Leone, A.J. Measuring qualitative information in capital markets research: Comparison of alternative methodologies to measure disclosure tone. Account. Rev. 2016, 91, 153-178. [CrossRef]

80. Short, J.C.; Broberg, J.C.; Cogliser, C.C.; Brigham, K.H. Construct validation using computer-aided text analysis (CATA) an illustration using entrepreneurial orientation. Organ. Res. Methods 2010, 13, 320-347. [CrossRef]

81. Richards, M.; Zellweger, T.; Gond, J.P. Maintaining moral legitimacy through worlds and words: An explanation of firms' investment in sustainability certification. J. Manag. Stud. 2017, 54, 676-710. [CrossRef]

82. Rahman, A.; Perera, H.; Ganesh, S. Accounting practice harmony, accounting regulation and firm characteristics. Abacus 2002, 38, 46-77. [CrossRef]

83. Lund, K.; Burgess, C. Producing high-dimensional semantic spaces from lexical co-occurrence. Behav. Res. Methods Instrum. Comput. 1996, 28, 203-208. [CrossRef]

84. Doran, J.S.; Peterson, D.R.; Price, S.M. Earnings conference call content and stock price: The case of REITs. J. Real Estate Financ. Econ. 2012, 45, 402-434. [CrossRef]

85. Engelberg, J.E.; Reed, A.V.; Ringgenberg, M.C. How are shorts informed? Short sellers, news, and information processing. J. Financ. Econ. 2012, 105, 260-278. [CrossRef] 
86. Hájek, P.; Henriques, R. Mining corporate annual reports for intelligent detection of financial statement fraud-A comparative study of machine learning methods. Knowl.-Based Syst. 2017, 128, 139-152. [CrossRef]

87. Fama, E.F.; French, K.R. Forecasting profitability and earnings. J. Bus. 2000, 73, 161-175. [CrossRef]

88. Chang, Y.B.; Kwon, Y. Ambiguities in valuing information technology firms: Do internet searches help? J. Bus. Res. 2018, 92, 260-269. [CrossRef]

89. Aragon-Correa, J.A.; Sharma, S. A contingent resource based view of proactive corporate environmental strategy. Acad. Manag. Rev. 2003, 28, 71-88. [CrossRef]

90. Kahneman, D.; Tversky, A. Prospect theory: An analysis of decision under risk. In Handbook of the Fundamentals of Financial Decision Making, Part I; The Econometric Society: Cleveland, OH, USA, 2013; pp. 99-127.

91. Hájek, P. Combining bag-of-words and sentiment features of annual reports to predict abnormal stock returns. Neural Comput. Appl. 2018, 29, 343-358. [CrossRef]

(C) 2018 by the authors. Licensee MDPI, Basel, Switzerland. This article is an open access article distributed under the terms and conditions of the Creative Commons Attribution (CC BY) license (http://creativecommons.org/licenses/by/4.0/). 